\title{
Ontogeny of Insulin Effect in Fetal Sheep
}

\author{
RICHARD D. MOLINA, THOMAS D. CARVER, AND WILLIAM W. HAY, JR
}

Department of Obstetrics, Gynecology and Reproductive Sciences. Liniversity of Pittshurgh School of Medicine. Pittshurgh. Pennsy/vania 15213-3180/R.D.11.J, and Division of Perinatal Medicine and Re'search. Liniversity of



\begin{abstract}
ABSTRACl. Compared with fetuses near term, midgestation fetal sheep at about $75 \mathrm{~d}$ of gestation have higher weight-specific glucose uptake rates, higher plasma glucose concentrations, lower plasma insulin concentrations, higher red blood cell insulin receptor concentrations and affinity, and a lower proportion of body weight accounted for by potentially insulin-sensitive skeletal muscle. Based on these observations, we measured the net rate of glucose uptake by the fetus from the uteroplacenta under basal and hyperinsulinemic conditions in eight fetal sheep at $76 \mathrm{~d}$ of gestation and eight fetal sheep at $132 \mathrm{~d}$ of gestation (term $\approx 150 \mathrm{~d})$. Hyperinsulinemia $(414 \pm 90 \mathrm{pNI})$ in the $76-\mathrm{d}$ fetal sheep decreased plasma glucose concentration by 0.20 $\pm 0.03 \mathrm{mNI}(-13 \%, p<0.01)$ and increased the net rate of glucose uptake $(8.4 \pm 2.2 \mu \mathrm{mol} / \mathrm{min} / \mathrm{kg},+21.3 \%, p<$ $0.05)$ and glucose clearance $(11.4 \pm 2.6 \mathrm{~mL} / \mathrm{min} / \mathrm{kg},+39 \%$, $p<0.01$ ). In the 132-d fetuses, a comparable hyperinsulinemia (306 $\pm 36 \mathrm{pNI})$ decreased plasma glucose concentration $(-0.31 \pm 0.02 \mathrm{mMl},-26 \%, p<0.05)$ and increased glucose clearance $(16.7 \pm 1.8 \mathrm{~mL} / \mathrm{min} / \mathrm{kg},+73.6 \%, p<$ $0.05)$ to a greater extent than in the 76 -d fetuses $(p<0.05$ and $p<0.01$, respectively). Net glucose uptake rate increased significantly in the 132-d fetuses $(6.7 \pm 1.1 \mu \mathrm{mol} /$ $\min / \mathrm{kg},+27.5 \%, p<0.05$ ), but not differently from the 76-d fetuses $(p=0.21)$. These data define brisk and significant effects of insulin on glucose metabolism in fetal sheep, even as early as $\approx 50 \%$ of gestation. The midgestation fetal sheep, particularly in relation to its larger fractional content of body water and smaller fractional content of insulin-sensitive tissues, demonstrates glucose metabolic responses to insulin at least as great as those that occur near term. (Pediatr Res 34: 654-660, 1993)
\end{abstract}

The midgestation fetal lamb at about 70 to $80 \mathrm{~d}$ of gestation, or about $50 \%$ of fetal life, has quite high weight-specific rates of net glucose uptake compared with the near-term fetus $(40-50$ versus $20-30 \mu \mathrm{mol} / \mathrm{min} / \mathrm{kg}$, respectively) (1, 2). At midgestation, plasma glucose is higher than at term (1.4-1.6 versus $1.0-1.1$ $\mathrm{mM}$, respectively) (3), but plasma insulin is lower (24-30 versus 65-80 pM, respectively). Based on the relatively high rates of glucose uptake, it is important to obtain direct evidence for the roles of fetal plasma glucose and insulin concentrations in regulating glucose metabolism at earlier stages of fetal life. The effects of insulin may be particularly important in view of observations

Received February 18, 1993; accepted June 24, 1993

Correspondence: William W. Hay. Jr., M.D., Division of Perinatal Medicine and Research, University of Colorado School of Medicine (Box B-195), 4200 East Ninth Ave., Denver, CO 80262.

Supported by Research Grants DK 35836 and HD20761 (W.W.H.) and Training Grant HD07186 (R.D.M.) from the National Institutes of Health. T.D.C. is supported by the United States Army. The opinions expressed herein are those of the authors and do not necessarily represent those of the U.S. Army or the Department of Defense. in fetal sheep of decreases in red blood cell insulin receptor concentration and affinity that occur simultancously with increasing plasma insulin concentrations over the second half of gestation (even though the relation between red blood cell insulin receptor number and/or affinity and glucose uptake by other insulin-sensitive tissues is not clear) $(4,5)$. Furthermore, carcass analysis studies have shown an increase in the proportion of body weight accounted for by skeletal muscle, the major insulinsensitive fetal tissue, over the second half of gestation $(1,2,6)$. Based on these observations, we considered that there might be significant differences in the effect of fetal plasma insulin concentration on fetal glucose metabolism between the midgestation fetus and the fetus near term. The following studies were done to measure net glucose uptake (representing fetal glucose utilization) by mid- and late-gestation fetal sheep and to compare the effect on fetal glucose metabolism of insulin infusions that produced a variety of hyperinsulinemic states among studied animals.

\section{MATERIALS AND METHODS}

Animal surgery, maintenance, and preparation for study: Columbia-Rambouillet mixed breed pregnant ewes each carrying a single fetus were obtained from Nebeker Ranch, Santa Monica, $\mathrm{CA}$. The ewe and fetus were surgically prepared at about 70 or $130 \mathrm{~d}$ of gestation. The ewe was anesthetized with spinal anesthesia $(6 \mathrm{mg}$ of tetracaine hydrochloride in $10 \% \mathrm{wt} / \mathrm{vol}$ dextrose in water) after sedation with i.v. pentobarbital (approximately 5 $\mathrm{mg} / \mathrm{kg}$ ). Maternal femoral arterial (sampling) and venous (infusion) catheters were placed via a groin incision. After midline laparotomy, hysterotomy was performed to place fetal catheters. In the 70-d group of fetuses, an infusion catheter was placed into one umbilical vein and a more distal sampling catheter was placed into the other umbilical vein using placental cotyledonary branch vessels in both cases; another sampling catheter was placed into an umbilical artery, also via a placental cotyledonary branch vessel (7). Arterial, venous, and umbilical venous catheters in the near-term group of fetuses were placed directly using standard methods (8). The catheters were tunneled through a flank incision in the ewe and secured in a plastic pouch attached to the ewe's skin. Catheters were filled and flushed daily with $0.9 \% \mathrm{wt} / \mathrm{vol}$ sodium chloride containing $30 \mathrm{U} / \mathrm{mL}$ sodium heparin. The ewe received penicillin $(1.5 \mathrm{~g})$ and streptomycin $(1 \mathrm{~g})$ intramuscularly and ampicillin $(500 \mathrm{mg})$ was placed in the amniotic fluid at the time of surgery.

The sheep were allowed to recover from surgery for 3 to $5 \mathrm{~d}$ before study, at which time maternal and fetal blood glucose and oxygen concentrations were normal for unanesthetized, healthy sheep in our laboratory, and the ewes ate a normal diet (ad libitum intake of alfalfa pellets, water, and mineral block). Each sheep was kept in a separate cart, but at least two sheep were kept in the same room for company. Study rooms were controlled to $65 \pm 5^{\circ} \mathrm{C}$ with $16 \mathrm{~h}$ of light and $8 \mathrm{~h}$ of darkness. At the end of the studies, each ewe and fetus was killed with a rapid i.v. infusion of T-61 euthanasia solution (Taylor Pharmaceutical, 
Decatur, IL). All animal surgical, maintenance, and experimental procedures were approved by the University of Colorado Health Sciences Center Animal Care and Use Committee.

Study design. On the day of study, starting at time zero, antipyrine or tritiated water to measure umbilical blood flow by the steady state diffusion technique was infused into the umbilical vein infusion catheter at a constant rate $[0.09 \mathrm{~mL} / \mathrm{min}$ antipyrine infusion, near term group; and $0.05 \mathrm{~mL} / \mathrm{min}(n=7)$ or 0.09 $\mathrm{mL} / \mathrm{min}(n=4)$ tritiated water infusion, midgestation group] ( 9 , 10). The tritiated water was used only in the midgestation animals to conserve blood volume because the assay for ${ }^{3} \mathrm{H}_{2} \mathrm{O}$ requires only $100 \mu \mathrm{L}$ of blood compared with $500-1000 \mu \mathrm{L}$ for antipyrine. Previous studies in our laboratory have found no difference between the two tracers for determining umbilical or uterine blood flow rates at either mid- or late gestation $(3,10)$. This technique has been shown to produce steady state transplacental fluxes of antipyrine or tritiated water by $60 \mathrm{~min}$ of infusion. Blood samples were withdrawn simultancously from the umbilical vein and artery catheters at 90,100,110, and 120 min for the control period. After this period, insulin was infused through the umbilical venous infusion catheter without altering the rate of blood flow tracer infusion. Different rates of insulin were infused to produce different estimated plasma insulin concentrations using $120 \mathrm{~mL} / \mathrm{kg}$ fetal weight for fetal blood volume, the measured hematocrit to determine plasma volume, and an extracellular insulin space of $150 \mathrm{~mL} / \mathrm{kg}$ fetal body weight. Fetal body weight was estimated from previous data in our laboratory for this breed of sheep (11). Four additional sets of blood samples were taken from the umbilical venous and arterial catheters at 210, 220, 230, and $240 \mathrm{~min}$ from the start of the study (commencing $90 \mathrm{~min}$ after starting the insulin infusion). Blood samples $(1.5 \mathrm{~mL})$ drawn into plastic syringes lined with a mixture of EDTA and sodium fluoride were used to measure blood glucose and antipyrine or tritiated water concentrations and, after centrifugation in a refrigerated centrifuge, plasma glucose and insulin concentrations. Blood oxygen contents were measured in 200- $\mu \mathrm{L}$ blood samples drawn anaerobically into glass capillaries lined with dried heparin and sodium fluoride. After each blood sample was obtained, an equal volume of blood was replaced immediately with maternal blood. The total isovolumetric exchange during the study averaged $15 \%$ of blood volume for the midgestation fetuses and $3-4 \%$ for the near-term fetuses.

In three separate midgestation fetuses, ${ }^{14} \mathrm{C}_{6}$-glucose was infused along with tritiated water to measure fetal glucose utilization rate. Blood samples were obtained only in a control period at the same times as for the other study animals, but they included an additional $0.5 \mathrm{~mL}$ volume for measurement of blood tracer glucose concentration. Blood replacement was still isovolumetric.

Infiusates. Antipyrine for infusion was prepared as a $10 \%$ solution in $0.9 \% \mathrm{wt} / \mathrm{vol}$ sodium chloride in water and was infused at about $3 \mathrm{mg} / \mathrm{kg}$ fetal body weight per min. Tritiated water was made up in $0.9 \% \mathrm{wt} / \mathrm{vol}$ sodium chloride in water $(100 \mu \mathrm{Ci} / 30$ $\mathrm{mL}$ ) and infused at about $0.1 \mu \mathrm{Ci} / \mathrm{min} / \mathrm{kg}$ fetal body weight. Insulin (pure pork insulin, Eli Lilly Co., Indianapolis, IN) was diluted in a mixture of $0.9 \% \mathrm{wt} / \mathrm{vol}$ sodium chloride in water $(30 \mathrm{~mL})$ and maternal sheep plasma $(5 \mathrm{~mL})$ and infused at 0.1 $\mathrm{mL} / \mathrm{min}$ producing estimated insulin infusion rates ranging from about 0.2 to about $6.0 \mathrm{pmol} / \mathrm{min} / \mathrm{kg}$ fetal body weight. A priming dose of insulin was given at a logarithmically decreasing rate of infusion over $10 \mathrm{~min}$ (the total priming dose over $10 \mathrm{~min}$ averaging twice the final infusion rate) ending with the desired constant rate of infusion $(12) .{ }^{14} \mathrm{C}_{6}$-glucose was obtained from ICN Radiochemicals, Irvine, CA, and mixed with $0.9 \% \mathrm{wt} / \mathrm{vol}$ sodium chloride in water to provide a solution that contained about $10-15 \mathrm{mCi} / \mathrm{mL}$ and was infused into the fetus at about $0.3 \mathrm{mCi} / \mathrm{min} / \mathrm{kg}$ fetal body weight. The concentration of ${ }^{14} \mathrm{C}_{6}$ glucose in the infusate was the same before and after the study. The glucose tracer was given as a primed, constant infusion. The prime dose was estimated at 100 times the dose infused in $1 \mathrm{~min}$ at the constant infusion rate.

Analytical methods. Blood antipyrine and tritiated water concentrations were measured according to the methods of Meschia 't al. (9) and Wilkening 't al. (10). Whole blood oxygen content was calculated from the product of the blood oxygen capacity and the oxyhemoglobin percent saturation measured within 10 min after sampling in an automatic direct-reading spectrophotometer (OSM-2 Hemoximeter, Radiometer, Copenhagen, Denmark). Blood and plasma glucose concentrations were measured by a spectrophotometric glucose oxidase assay (Sigma Chemical Co., St. Louis, MO). Plasma insulin was measured on samples that had been frozen at $-70^{\circ} \mathrm{C}$ until the time of assay by a double-antibody RIA (Cambridge Diagnostics, Billerica, MA) with $5 \%$ intraassay and $7 \%$ interassay coeflicients of variation. Ovine standards were generously provided by Eli Lilly Company. Blood radioactive glucose concentration was measured according to the method of Hay et al. (8).

C'alculations. Net fetal glucose and oxygen uptake rates were calculated as the products of umbilical blood flow and umbilical venoarterial blood concentration differences. Net fetal radioactive glucose uptake rate was calculated as the difference between total tracer infusion rate into the fetus minus the net rate of tracer glucose diffusion into the placenta via the umbilical circulation (calculated as umbilical blood flow rate times the umbilical arteriovenous blood tracer concentration difference). Fetal glucose utilization rate was calculated as net fetal tracer glucose uptake rate divided by fetal arterial plasma glucose specific radioactivity (8). Fetal glucose clearance rate was calculated as net fetal glucose uptake rate divided by fetal arterial plasma glucose concentration: this calculation assumes that fetal glucose uptake rate and fetal glucose utilization rate are equal.

Statistics. For each animal, data were first summarized by means of the four samples collected during the control and the insulin infusion periods. These mean values were considered to represent steady state conditions for tracers, glucose, and oxygen. with steady state defined as less than a $\pm 5 \%$ variation of individual values for each parameter around the period mean value, with no consistent trend to increase or decrease. With these means used as data, paired and unpaired $t$ test and analysis of variance were used to test for significance of differences within and between the two gestational age groups. Differences were considered significant at $p<0.05$. A linear mixed effects model was used to compare the absolute and fractional rates of change for the two gestational age groups with respect to both glucose utilization and glucose concentration in response to insulin infusion (13).

\section{RESULTS}

Table 1 presents metabolic data in three normal fetal sheep at about $76 \mathrm{~d}$ of gestation (about $50 \%$ of gestation). In these three fetuses, the net rate of fetal glucose uptake from the umbilical circulation (measured using the Fick principle) was not different $(p>0.5)$ from the glucose utilization rate (measured using ${ }^{14} \mathrm{C}_{6^{-}}$glucose tracer). With this information from these three animals, fetal glucose uptake rate was considered equivalent to fetal glucose utilization rate in all other animals in the present study, because all were studied at normal plasma glucose concentrations and/or normal or greater than normal plasma insulin concentrations, both conditions associated with the absence of measurable glucose production in fetal sheep $(8,11,12,14)$.

Eight additional midgestation fetuses were studied at a mean gestational age of $76 \mathrm{~d}$ under basal conditions and after a 2-h insulin infusion (Table 2). With insulin infusion, plasma insulin concentration increased by $390 \pm 90 \mathrm{pM}$ (directly related to the insulin infusion rate, $r=0.4, p<0.05)$ and plasma glucose concentration decreased by $0.20 \pm 0.03 \mathrm{mM}(-13 \%, p<0.01)$. Furthermore, the plasma glucose concentration decreased in every animal (Fig. 1). In response to the decrease in plasma 
Table 1. Metabolic data for three midgestation, 76-d fetuses comparing net glucose uptake rate with glucose utilization rate

\begin{tabular}{|c|c|c|c|c|}
\hline & \multicolumn{3}{|c|}{ Animal number } & \multirow[b]{2}{*}{ Mean (SEM) } \\
\hline & 1 & 2 & 3 & \\
\hline Gestational age (d) & 79 & 75 & 74 & $76(1.5)$ \\
\hline Fetal weight $(\mathrm{kg})$ & 0.267 & 0.161 & 0.158 & $0.195(0.036)$ \\
\hline Plasma glucose $(\mathrm{mM})$ & 1.74 & 1.49 & 1.48 & $1.57(0.09)$ \\
\hline Plasma insulin (pM) & 24 & 30 & 18 & $24(4)$ \\
\hline Blood $\mathrm{O}_{2}$ content $(\mathrm{mM})$ & 3.35 & 3.40 & 2.51 & $3.09(0.29)$ \\
\hline Glucose uptake $(\mu \mathrm{mol} / \mathrm{min} / \mathrm{kg})$ & 40.6 & 48.3 & 54.9 & $48.2(3.9)$ \\
\hline Glucose utilization $(\mu \mathrm{mol} / \mathrm{min} / \mathrm{kg})$ & 41.1 & 48.3 & 53.9 & $48.2(3.9)$ \\
\hline $\mathrm{O}_{2}$ uptake $(\mu \mathrm{mol} / \mathrm{min} / \mathrm{kg})$ & 405 & 389 & 496 & $430(33)$ \\
\hline Glucose clearance $(\mathrm{mL} / \mathrm{min} / \mathrm{kg})$ & 23.8 & 42.3 & 36.8 & $34.3(5.5)$ \\
\hline Umbilical blood flow $(\mathrm{mL} / \mathrm{min} / \mathrm{kg})$ & 262 & 227 & 244 & $244(10)$ \\
\hline
\end{tabular}

Table 2. Metabolic data for basal and insulin infusion periods in the 76-d fetuses /mean (SEM)]

\begin{tabular}{|c|c|c|}
\hline & Basal & $\begin{array}{l}\text { Insulin } \\
\text { infused }\end{array}$ \\
\hline No. of sheep & 8 & 8 \\
\hline Gestational age (d) & $76(0.5)$ & $76(0.5)$ \\
\hline Weight (kg) & $0.22(0.02)$ & $0.22(0.02)$ \\
\hline Plasma glucose (mM) & $1.49(0.06)$ & $1.29(0.07)^{*}$ \\
\hline Plasma insulin (pM) & $24(3)$ & $414(90)^{*}$ \\
\hline Blood $\mathrm{O}_{2}$ content $(\mathrm{mM})$ & $3.87(0.22)$ & $3.38(0.42)^{*}$ \\
\hline Umbilical blood flow $(\mathrm{mL} / \mathrm{min} / \mathrm{kg})$ & $367(18)$ & $348(19)$ \\
\hline Fetal oxygen uptake $(\mu \mathrm{mol} / \mathrm{min} / \mathrm{kg})$ & $409(23)$ & $429(18)$ \\
\hline $\begin{array}{l}\text { Fetal glucose uptake }\left(G U R_{f}\right)(\mu \mathrm{mol} / \\
\min / \mathrm{kg})\end{array}$ & $41.1(3.3)$ & $49.4(5.0)^{*}$ \\
\hline Fetal glucose clearance $(\mathrm{mL} / \mathrm{min} / \mathrm{kg})$ & $28.1(2.4)$ & $39.5(4.6)^{*}$ \\
\hline $\begin{array}{l}\text { Change in glucose concentration } \\
(\mathrm{mM})\end{array}$ & $-0.20(0.03) \dagger$ & \\
\hline$\%$ Change in glucose concentration & $-12.9(2.4) \dagger$ & \\
\hline $\begin{array}{l}\text { Change in insulin concentration } \\
(\mathrm{pM})\end{array}$ & $390(90)$ & \\
\hline $\begin{array}{l}\text { Change in glucose uptake ( } \mu \mathrm{mol} / \\
\min / \mathrm{kg} \text { ) }\end{array}$ & $8.3(2.2)$ & \\
\hline$\%$ Change in glucose uptake & $21.3(5.7)$ & \\
\hline $\begin{array}{l}\text { Change in glucose clearance }(\mathrm{mL} / \\
\min / \mathrm{kg})\end{array}$ & $11.4(2.6) \dagger$ & \\
\hline$\%$ Change in glucose clearance & $39.0(7.2) \dagger$ & \\
\hline
\end{tabular}

${ }^{*} p<0.05$ between basal and insulin infusion periods.

$\dagger p<0.05$ between 76-d and 132-d groups.

glucose concentration, fetal glucose uptake rate increased by 8.3 $\pm 2.2 \mu \mathrm{mol} / \mathrm{min} / \mathrm{kg}(+21.3 \%, p<0.05)$ and the clearance of glucose increased by $11.4 \pm 2.6 \mathrm{~mL} / \mathrm{min} / \mathrm{kg}(+39.0 \%, p<0.01)$. The increase in fetal glucose uptake rate (Fig. 2) and plasma glucose clearance occurred in every animal. Blood oxygen content decreased by $12.7 \%$, which was a significant change, probably due to a failure to exactly transfuse the fetuses isovolumetrically, as well as the decrease in blood oxygen saturation resulting from dilution of fetal hemoglobin with transfused adult $\mathrm{Hb}$. Net fetal oxygen uptake increased in five animals and decreased in three; the overall mean change was positive $(+20 \pm 15 \mu \mathrm{mol} /$ $\mathrm{min} / \mathrm{kg},+5 \%)$, but this increase was not significant.

For comparison, eight additional fetuses were studied at a mean gestational age of $132 \mathrm{~d}$ under basal conditions and after $2 \mathrm{~h}$ of insulin infusion (Table 3). The basal plasma glucose concentration, plasma insulin concentration, fetal glucose uptake rate, and fetal oxygen uptake rate were significantly different from the 76 -d group $(-24 \%, p<0.01$ for plasma glucose concentration; +3-fold, $p<0.01$ for plasma insulin concentration; $-36 \%, p<0.05$ for fetal glucose uptake rate; and $-26 \%, p<$ 0.05 for fetal oxygen uptake rate).

Plasma insulin concentration was directly related to the insulin infusion rate $(r=0.6, p<0.01)$ Although the mean absolute increase in plasma insulin concentration was not different between the two groups $(p=0.15)$, the metabolic response to insulin was significantly greater in the late-gestation. 132-d group: mean glucose concentration decreased by $0.31 \pm 0.02 \mathrm{mM}$ $(-26 \%, p<0.01$, or twice the percent decrease in the 76 -d group. $p<0.05$ ); glucose uptake (utilization) rate increased by $6.7 \pm$ $1.1 \mu \mathrm{mol} / \mathrm{min} / \mathrm{kg}(+26 \%, p<0.05$, or about the same as for the 76-d group); and glucose clearance rate increased $16.7 \pm 1.8 \mathrm{~mL} /$ $\mathrm{min} / \mathrm{kg}(+73.6 \%, p<0.01$, or $46 \%$ greater than in the $76-\mathrm{d}$ group). These changes were positive in every animal. Blood oxygen content decreased by $10.2 \%$, but this change was not significant. Net fetal oxygen uptake rate increased in three animals and decreased in five but overall did not change significantly, similar to the 76-d group.

Figure 3 compares the mean and individual values for net fetal glucose uptake rate from the umbilical circulation versus fetal plasma insulin concentration in the midgestation, 76-d group and the near term, 132-d group. Mean fetal glucose uptake rate in the 132-d group increased $6.7 \pm 1.1 \mu \mathrm{mol} / \mathrm{min} / \mathrm{kg}(+27.5 \%)$, which was not different $(p=0.21)$ from the mean increase of $8.3 \pm 2.2 \mu \mathrm{mol} / \mathrm{min} / \mathrm{kg}(+21 \%)$ in the $76-\mathrm{d}$ group. Thus, the slopes of the two lines representing the mean increase in glucose uptake rate versus the mean increase in insulin concentration were not different between the two groups of animals for absolute change $(p=0.24)$ or percent change $(p=0.72)$. This lack of difference does not imply equivalence, however, because during the insulin infusion, plasma glucose concentration decreased to a greater extent in the near term group than it did in the midgestation group, thereby decreasing to a greater extent the combined effect of the plasma glucose and insulin concentrations that together (additively) determine the rate of transfer of glucose out of the fetal plasma and into fetal tissues (equal to glucose uptake rate) (14).

Fetal dry weight (obtained by drying three samples of total fetal carcass homogenate to constant weight in an oven) was $0.024 \pm 0.002 \mathrm{~kg}$ in the $76-\mathrm{d}$ group and $0.700 \pm 0.070 \mathrm{~kg}$ in the $132-d$ group. Wet weight in the 76-d group was about $6 \%$ of that in the 132-d group, dry weight was about $3 \%$, and the dry to wet weight ratio was about $11 \%$ in the 76-d group compared with about $20 \%$ in the 132 -d group. Table 4 presents calculated rates of fetal glucose uptake and clearance based on the measured absolute rates and the wet and dry weights, respectively.

Umbilical blood flow per $\mathrm{kg}$ of wet weight was 2.2-fold greater in the 76-d group than in the 132-d group $(p<0.001)$. Umbilical blood flow did not change significantly from the basal to the insulin infusion study periods in either group of animals.

\section{DISCUSSION}

The results of the present study demonstrate several important features of glucose metabolism in midgestation fetal sheep. First, although insulin has been used before to decrease fetal plasma glucose in midgestation fetal sheep (3), these are the first studies 


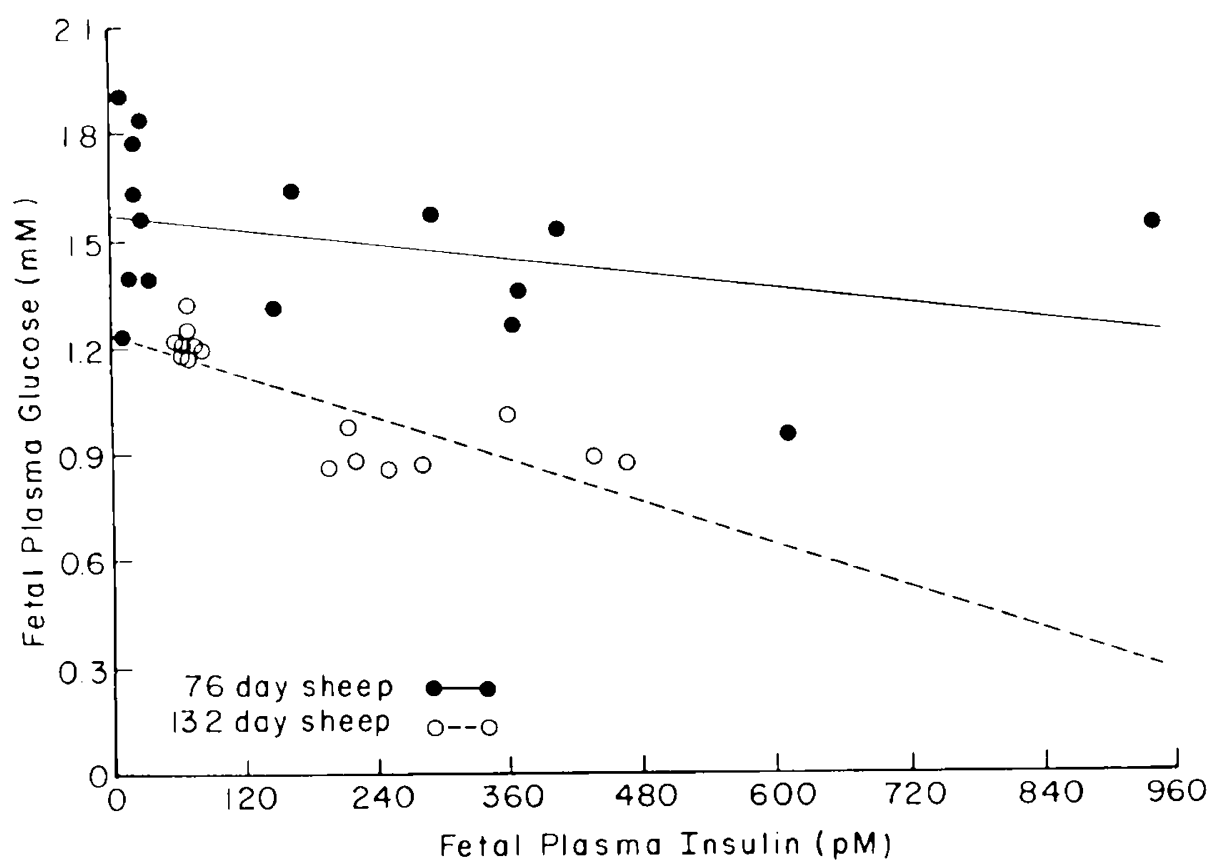

Fig. 1. Relationship between fetal arterial plasma glucose concentration $\left(G_{i}\right)$ and fetal arterial plasma insulin concentration $\left(I_{i}\right)$ in the $76-d$ group of fetal sheep $(0)\left[\mathrm{G}_{\mathrm{f}}=1.56-0.00034 \cdot\left(\mathrm{I}_{\mathrm{f}}\right), r^{2}=0.15, p=0.13\right]$ and the $132-\mathrm{d}$ group of fetal sheep $(O)\left[\mathrm{G}_{\mathrm{f}}=1.26-0.00094 \cdot\left(\mathrm{I}_{\mathrm{f}}\right), r^{2}=0.67, p=\right.$ $0.0001]$. The slope of the 132-d group is greater than that of the $76-\mathrm{d}$ group $(p<0.05)$.

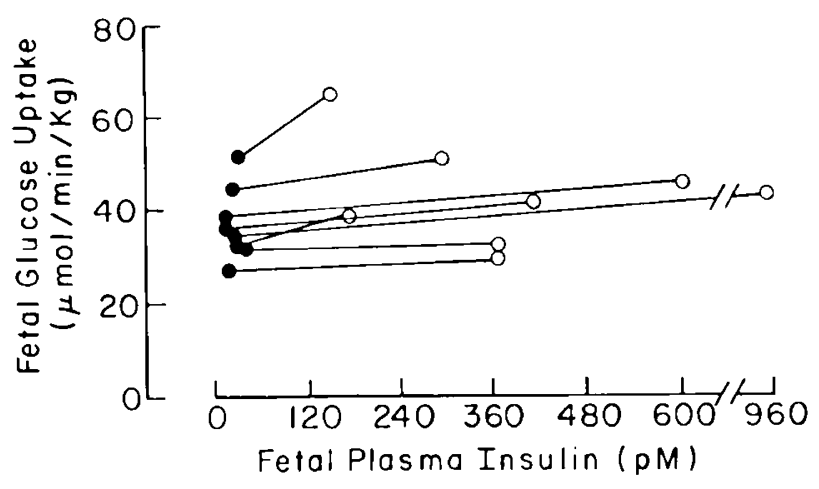

Fig. 2. Basal $(\bullet)$ and insulin infusion period $(O)$ rates of fetal glucose uptake in the 76-d group of fetal sheep. The insulin infusion period glucose uptake rates were greater than the basal rates in every case.

to quantify the effect of insulin on fetal glucose metabolism at this early gestational age. Second, net fetal glucose uptake rate was not different from fetal glucose utilization rate in three normal fetuses at a mean gestational age of $76 \mathrm{~d}$. Thus, as in near term fetal sheep, there is no evidence for fetal glucose production at midgestation, allowing the reasonable use of the net rate of fetal glucose uptake from the umbilical circulation to quantify the net rate of irreversible glucose disappearance from the fetal plasma, equal in steady state to fetal glucose utilization rate, and thus to calculate the rate of fetal glucose clearance. In this way, controlling factors such as fetal plasma glucose and insulin concentrations and the change in glucose concentration could be used to compare the effect of insulin on fetal glucose metabolism between midgestation and near term animals without adding considerable complexity and risk to animal condition at midgestation from the much larger blood volumes required for glucose tracer measurements relative to fetal blood volume.

There was greater variance observed in the 76-d fetuses for basal period glucose concentration and for the changes in insulin concentration, glucose concentration, glucose utilization rate, and glucose clearance rate that occurred with insulin infusion (Figs. 1 and 3; Tables 2 and 3). Statistically, the variability was
Table 3. Metabolic data for basal and insulin infusion periods in 132-d fetuse's [mean (SEM)]

\begin{tabular}{|c|c|c|}
\hline & Basal & $\begin{array}{l}\text { Insulin } \\
\text { infused }\end{array}$ \\
\hline No. of sheep & 8 & 8 \\
\hline Gestational age (d) & $131.5(2.2)^{*}$ & $131.5(2.2)$ \\
\hline Weight $(\mathrm{kg})$ & $3.48(0.23)^{*}$ & $3.48(0.23)$ \\
\hline Plasma glucose (mM) & $1.14(0.02)^{*}$ & $0.83(0.02) \dagger$ \\
\hline Plasma insulin (pM) & $72(2)^{*}$ & $306(36) \dagger$ \\
\hline Blood $\mathrm{O}_{2}$ content $(\mathrm{mM})$ & $3.34(0.28)$ & $3.01(0.32)$ \\
\hline $\begin{array}{l}\text { Umbilical blood flow }(\mathrm{mL} / \\
\min / \mathrm{kg})\end{array}$ & $164(11)^{*}$ & $168(11)$ \\
\hline $\begin{array}{l}\text { Fetal oxygen uptake ( } \mu \mathrm{mol} / \\
\min / \mathrm{kg} \text { ) }\end{array}$ & $303(14)^{*}$ & $297(14)$ \\
\hline $\begin{array}{l}\text { Fetal glucose uptake }\left(G_{U} R_{\mathrm{f}}\right) \\
(\mu \mathrm{mol} / \mathrm{min} / \mathrm{kg})\end{array}$ & $26.1(1.1)^{*}$ & $32.8(1.7)^{* \dagger}$ \\
\hline $\begin{array}{l}\text { Fetal glucose clearance }(\mathrm{mL} / \\
\min / \mathrm{kg})\end{array}$ & $23.3(1.2)^{*}$ & $40.0(2.1) \dagger$ \\
\hline $\begin{array}{l}\text { Change in glucose concentra- } \\
\text { tion }(\mathrm{mM})\end{array}$ & $-0.31(0.02)^{*}$ & \\
\hline $\begin{array}{l}\% \text { Change in glucose concen- } \\
\text { tration }\end{array}$ & $-26.3(0.23)^{*}$ & \\
\hline $\begin{array}{l}\text { Change in insulin concentra- } \\
\text { tion }(\mathrm{pM})\end{array}$ & $234(36)$ & \\
\hline $\begin{array}{l}\text { Change in glucose uptake } \\
(\mu \mathrm{mol} / \mathrm{min} / \mathrm{kg})\end{array}$ & $6.7(1.1)$ & \\
\hline$\%$ Change in glucose uptake & $27.5(6.7)$ & \\
\hline $\begin{array}{l}\text { Change in glucose clearance } \\
(\mathrm{mL} / \mathrm{min} / \mathrm{kg})\end{array}$ & $16.7(1.8)^{*}$ & \\
\hline$\%$ Change in glucose clearance & $73.6(10.1)^{*}$ & \\
\hline
\end{tabular}

${ }^{*} p<0.05$ between $76-\mathrm{d}$ and $132-\mathrm{d}$ groups.

$\dagger p<0.05$ between basal and insulin infusion periods.

primarily due to interanimal rather than within-animal variation. Some of this increased variability is likely due to the limitation of Fick principle measurements in accurately discriminating relatively low rates, and changes in rates, of glucose utilization. There also is the possibility that the midgestation fetuses may have more variable number and function of insulin receptors 




Fig. 3. Relationship between fetal glucose uptake rate $\left(G U R_{f}\right)$ and fetal arterial plasma insulin concentration in the 76-d group of fetal sheep $(\bullet)$ $\left[G U R_{f}=46.8+0.14 \cdot\left(I_{f}\right), r^{2}=0.10, p=0.17\right]$ and the 132-d group of fetal sheep $(O)$ [GUR $\left.R_{f}=26.9+0.26 \cdot\left(I_{f}\right), r^{2}=0.52, p=0.002\right]$. The slopes of the two linear regressions are not different $(p>0.2)$.

Table 4. Absolute, wet weight-specific, and dry weight-specific rates of fetal glucose uptake (utilization) and glucose clearance [mean(SEM))

\begin{tabular}{|c|c|c|c|c|}
\hline & \multicolumn{2}{|c|}{ 76-d sheep } & \multicolumn{2}{|c|}{ 132-d sheep } \\
\hline & Basal & Insulin infusion & Basal & Insulin infusion \\
\hline \multicolumn{5}{|l|}{ Fetal glucose uptake } \\
\hline$\mu \mathrm{mol} / \mathrm{min}$ & $8.8(0.5)$ & $11.1(1.1)^{*}$ & $91.1(4.4)$ & $115.0(5.0)^{*}$ \\
\hline$\mu \mathrm{mol} / \mathrm{min} / \mathrm{kg}$ wet weight & $41.1(3.3)$ & $49.4(5.0)^{*}$ & $26.1(1.1)$ & $32.8(1.7)^{*}$ \\
\hline$\mu \mathrm{mol} / \mathrm{min} / \mathrm{kg}$ dry weight & $381(39)$ & $481(62)^{*}+$ & $131(7)$ & $165(7)^{*}$ \\
\hline \multicolumn{5}{|l|}{ Fetal glucose clearance } \\
\hline $\mathrm{mL} / \mathrm{min}$ & $6.2(0.5)$ & $8.7(1.0)^{*}$ & $81.1(4.2)$ & $139.2(7.3)^{*}$ \\
\hline $\mathrm{mL} / \mathrm{min} / \mathrm{kg}$ wet weight & $28.1(2.4)$ & $39.5(4.6)^{*}$ & $23.3(1.2)$ & $40.0(2.1)^{*}$ \\
\hline $\mathrm{mL} / \mathrm{min} / \mathrm{kg}$ dry weight & $246.2(21.0)$ & $335.9(41.1)^{*} \dagger$ & $116.5(6.0)$ & $200.8(10.5)^{*}$ \\
\hline
\end{tabular}

$* p<0.05$ between basal and insulin infusion periods.

$\dagger p<0.05$ between $76 \mathrm{~d}$ group and $132 \mathrm{~d}$ group.

and/or glucose transporters or more variable rates of glucose metabolism. Finally, differences in the body proportions of glucose-using organs are relatively marked over short periods of gestation at this early stage of development and also may account for some of the variability in glucose metabolism and/or insulin action.

Based on the decrease in fetal glucose concentration and the increase in fetal glucose clearance, a comparable degree of hyperinsulinemia had a greater effect near term than at midgestation. This difference was not observed for the effect of insulin on fetal glucose uptake, but in this case plasma glucose concentration during the insulin infusion decreased to a greater extent in the 132-d group than in the 76-d group. This difference precludes direct comparison because plasma glucose and insulin concentration are additive in their effects to promote the transfer of glucose into the tissues from the plasma, at least as measured by total fetal glucose utilization (14). Thus, the greater decrease in plasma glucose concentration in the 132-d group would be expected to produce a relatively lower fetal glucose uptake rate in these fetuses. To account for this difference in the change of glucose concentration between the two groups, we calculated for the near term group, using the basal and final fetal plasma glucose and insulin concentrations measured in the present midgestation group, the expected fetal glucose uptake rate that would occur according to our previous ovine fetal glucose utilization model that described the simultaneous effects of fetal plasma glucose and insulin concentrations on fetal glucose utilization rate (14). This model was developed mathematically from a large number of simultaneous pairs of plasma glucose and insulin concentrations collected among basal, glucose infusion, and insulin infusion conditions in near term fetal sheep; the model showed saturation kinetics for both plasma glucose and insulin concentrations on fetal glucose uptake rate, but the effects of each were additive rather than interactive. Based on this model, the basal period glucose uptake rate is greater in the midgestation fetuses than estimated for the near term group $(p<0.01)$ (Fig. 4), but the increase in fetal glucose uptake rate for an equivalent change in insulin concentration is calculated by the model to be greater for the near term group than occurred with the midgestation group $(\Delta 0.06 \mu \mathrm{mol} / \mathrm{min} / \mathrm{kg}$ glucose uptake per $\Delta 1.0 \mathrm{pM}$ insulin, near term group; $\lrcorner 0.02 \mu \mathrm{mol} / \mathrm{min} / \mathrm{kg}$ glucose uptake per $د 1.0$ pM insulin, midgestation group: $p<0.05$ ).

It also is possible that the glucose uptake rates in the 76-d group of fetuses during the hyperinsulinemia study period are underestimates of insulin effect, because the mean fetal glucose concentration decreased by only $0.20 \mathrm{mM}$ as insulin increased to a mean value of $414 \mathrm{pM}$. Our near term fetal glucose uptake rate versus glucose-by-insulin concentration model would predict a nonsignificant change in glucose uptake rate with such a small change in glucose concentration. Even if plasma glucose remained at the basal study period mean value of $1.5 \mathrm{mM}$ during the increase in the mean insulin concentration to $414 \mathrm{pM}$, the near term model would predict a nonsignificant increase in fetal glucose uptake rate from 49.4 to $52.2 \mu \mathrm{mol} / \mathrm{min} / \mathrm{kg}$. presumably because at these glucose and insulin concentrations the capacity for cellular glucose uptake throughout the fetal body is nearly saturated. It is also possible that both $76-\mathrm{d}$ and 132-d measurements of glucose metabolism are underestimates, because during the insulin infusion period, counterregulatory hormone responses, particularly of epinephrine, may limit the effect of insulin to promote cellular glucose uptake $(15,16)$. This aspect of fetal glucose metabolism has not been experimentally examined.

Several studies have demonstrated an increase in plasma insulin concentration in fetal sheep over the second half of gestation 




Fig. 4. Relationship between fetal glucose uptake rate $\left(G U R_{f}\right)$ and fetal arterial plasma insulin concentration for the 76-d group of fetuses $(--\bullet)$ and the 132-d group of fetuses $(\mathrm{O}-\mathrm{O})$. Also included as "near term model (76-d-data)" is the predicted relationship ( $\square-.-.-\square$ ) between GUR $_{\mathrm{f}}$ and fetal arterial plasma insulin concentration using the 76-d fetal values for plasma glucose concentration and plasma insulin concentration according to a previously published (14) model of glucose utilization versus glucose-by-insulin concentrations in near term fetal sheep. According to this model, basal $G_{U} R_{f}$ is predicted to be lower and the increase in fetal glucose uptake rate $\left(\Delta G U R_{1}\right)$ versus a change in fetal plasma insulin concentration $\left(\Delta \mathrm{I}_{f}\right)$ is predicted to be greater than was measured in the 76-d fetal sheep at the same plasma glucose and insulin concentrations $(p<0.05)$.

at the same time that there is a variable change of insulin receptor concentrations on a variety of tissue-specific cells (3-5). Thus, it is important that the present data demonstrate that the balance of insulin effect is in favor of an increase in fetal glucose utilization in response to insulin over the second half of gestation. Whether this change is due to an increase in insulin responsiveness of all insulin-sensitive tissues or simply to the relative increase in the fraction of body weight that consists of insulinsensitive tissues is not known. For example, hindlimb tissues that presumably consist largely of skeletal muscle that is considered to be insulin sensitive increase from 14.5 to $22.0 \%$ of fetal body weight from 50 to $90 \%$ of gestation in fetal sheep, whereas the combined fractional weight of tissues that are considered to be relatively less insulin sensitive (e.g. liver, kidneys, heart, and brain) decreases from 12.4 to $6.3 \%(2,17)$. This speculative issue warrants further investigation, although it is consistent with fetal development of glucose and insulin-sensitive glucose transporters (18).

It also is important to consider that the fractional content of body water in the midgestation fetus decreases from over $90 \%$ at about $50 \%$ of gestation to just under $80 \%$ near term $(2,6,17)$. On this basis alone, wet weight-specific insulin sensitivity would increase. To account for this gestational decrease in body water content, we calculated rates of glucose metabolism and insulin action on a dry weight as well as a wet weight basis, similar to the customary comparison of cellular metabolic rates with cellular protein or DNA content. From this perspective, as shown in Table 4, the effect of insulin is as great as or greater at midgestation than near term. The mechanisms responsible for this significant effect of insulin at mid-versus late-gestation are not yet known, although it is interesting to speculate that increased fetal insulin receptor number at midgestation may be responsible in part $(4,5)$, especially because glucose transporter activity might be expected to increase with advancing fetal development, coincident with the relatively greater development of insulin-sensitive tissues such as skeletal muscle (18).
Finally, some studies in very preterm human infants have indicated a "sluggish" response of glucose metabolism to insulin (19-23). Glucose concentrations did not fall as fast or as much in these infants during an i.v. insulin infusion compared with mature infants, the plasma glucose-to-insulin concentration ratio in these very preterm infants tended to be much higher than in normal infants at term, and the amount of glucose needed to maintain a certain rate of glucose utilization at a given insulin concentration was lower in the very preterm infants. At least in the preterm human infants, however, glucose metabolism appears to "normalize" as postnatal age increases and general physiologic condition improves, suggesting that stress and stressrelated factors such as insulin-counterregulatory hormones are strongly prevalent after early preterm birth, providing factors and conditions that likely interfere with insulin action (24. 25). The present data therefore are important for defining brisk and significant effects of insulin on fetal glucose metabolism under normal conditions in healthy, nonstressed, nonanesthetized fetal animals. Under these conditions, the midgestation fetal sheep, particularly in relation to its relatively larger fractional content of body water and smaller fractional content of insulin-sensitive tissues, demonstrates glucose metabolic responses to insulin at least as great as those that occur near term.

Acknowledgments. The authors thank Gary Zerbe, Ph.D.. and Ann Esler, Department of Biometrics. University of Colorado School of Medicine, for statistical consultation.

\section{REFERENCES}

1. Bell AW, Kennaugh JM. Battaglia FC. Makowski EL. Meschia G 1986 Metaholic and circulatory studies of fetal lamb at midgestation. Am J Physiol 250:E538-E544

2. Bell AW, Battaglia FC. Meschia G 1987 Relationship between metaholic rate and hody size in the ovine fetus. J Nutr 117:1181-1186

3. Molina RA. Meschia G. Battaglia FC. Hay Jr WW 1991 Gestational maturation of placental glucose transfer capacity in sheep. Am J Physiol 261:R697R704

4. Kappy MS. Plotnick LP. Milley JR, Rosenberg A. Molteni RA. Jones Jr MD. Simmons MA 1981 Ontogeny of erythrocyte insulin binding in the sheep. Endocrinology 109:611-617

5. Sinha M. Ganguli S. Sperling MA 1981 Disappearance of erythrocyte insulin receptors during maturation in sheep. Diahetes $30: 411-415$

6. Battaglia FC. Meschia G 1986 An introduction to fetal physiology. Academic Press. Orlando. FL. pp $100-135$

7. Bell AW. Battaglia FC. Meschia G 1987 Methods for chronic studies of circulation and metabolism in the sheep conceptus at 70-80 days gestation. In: Nathanielsz. PW (ed) Animal Models in Fetal Medicine VI. Perinatology Press. Ithaca. NY. pp 38-54

8. Hay Jr WW, Sparks JW, Quissell BJ, Battaglia FC, Meschia G 1981 Simultaneous measurements of umbilical uptake, fetal utilization rate, and fetal turnover rate of glucose. Am J Physiol 240:E662-1:668

9. Meschia G. Cotter JR, Breathnach CS, Barron DH 1967 Simultaneous measurement of uterine and umbilical blood tlows and oxygen uptahe. Q J Exp Physiol Cogn Med Sci 52:1-8

10. Wilkening RB. Anderson S. Martensson L. Meschia G 1982 Placental transfer as a function of uterine blood flow. Am J Physiol 242:14+29-11436

11. Hay Jr W'W, Meznarich HK. Sparks JW. Battaglia FC. Meschia G 1985 Effect of insulin on glucose untake in near-term fetal lambs. Proc Soc Exp Biol Med 178:557-564

12. Hay Jr WW. Meznarich HK 1986 The effect of hyperinsulinemia on glucose utilization and oxidation and on oxygen consumption in the fetal lamb. Q J Exp Physiol 49:689-698

13. Hirst K. Zerbe GO. Boyle DW. Wilkening RB 1991 On nonlinear random effects models for repeated measurements. Communications in Statistics 20:46.3-478

14. Hay Jr WW, Meznarich HK. Di Giacomo JE. Hirst K. Zerbe GO 1988 Effects of insulin and glucose concentrations on glucose utilization in fetal sheep. Pediatr Res 23:381-387

15. Sperling MA. Christensen RA. Ganguli S. Anand R 1980 Adrenergic modulation of pancreatic hormone secretion in utero: studies in fetal sheep. Pediatr Res 14:203-208

16. Padbury JF. Polk DH, Newnham JP. Lam RW 1985 Neonatal adaptation: greater sympathoadrenal response in preterm than full-term fetal sheep at birth. Am J Physiol 248:E443-449

17. Rattray PV, Garret WM. East NE. Hinman N 1974 Growth, development and composition of the ovine conceptus and mammary gland during pregnancy. J Anim Sci 38:613-629 
18. Devaskar SU, Mueckler MM 1992 The mammalian glucose transporters. Pediatr Res $31: 1-13$

19. Goldman SL, Hirata T 1980 Attenuated response to insulin in very low birthweight infants. Pediatr Res 14:50-53

20. Binder ND. Raschko PK. Benda GI, Reynolds JW 1989 Insulin infusion with parenteral nutrition in extremely low birth weight infants with hypergly. cemia. J Pediatr 114:273-280

21. Pollak A. Cowett RM. Schwartz. R, Oh W 1978 Glucose disposal in low-hirthweight infants during steady-state hyperglycemia: effects of exogenous insulin administration. Pediatrics $61: 546-549$
22. Ogata ES 1986 Carbohydrate metabolism in the fetus and neonate and altered neonatal glucoregulation. Pediatr Clin North Am 33:25-45

23. Cowett RM, Oh W, Schwarty R 1983 Persistent glucose production during glucose infusion in the neonate. J Clin Invest 71:467-475

24. Cowett RM 1988 Decreased response to catecholamines in the newborn: effect on glucose kinetics in the lamb. Metabolism 37:736-740

25. Cowett RM 1988 Alpha adrenergic agonists stimulate neonatal glucose production less than beta adrenergic agonist in the lamb. Metabolism 37:8318.36 